\title{
Labour
}

Journal of Canadian Labour Studies

Le Travail

Revue d'Études Ouvrières Canadiennes

\section{Bridget Kenny, Retail Worker Politics, Race and Consumption in South Africa: Shelved in the Service Economy}

\section{Kaitlyn Matulewicz}

Volume 83, printemps 2019

URI : https://id.erudit.org/iderudit/1061056ar

DOI : https://doi.org/10.1353/1lt.2019.0024

Aller au sommaire du numéro

Éditeur(s)

Canadian Committee on Labour History

ISSN

0700-3862 (imprimé)

1911-4842 (numérique)

Découvrir la revue

Citer ce compte rendu

Matulewicz, K. (2019). Compte rendu de [Bridget Kenny, Retail Worker Politics, Race and Consumption in South Africa: Shelved in the Service Economy].

Labour / Le Travail, 83, 287-290. https://doi.org/10.1353/llt.2019.0024 d'utilisation que vous pouvez consulter en ligne. 
Cocking had been the mainstay contributor to the International Socialist Review for Australasia from 1907 to 1912, which Holland edited. Cocking kept diaries and common books, which the University of Newcastle has digitized. Wider transnational networks might also help to address the argument only really implicit in this book: Kirk does not accept the conventional wisdom that "socialism in the Antipodes derived much, but not all, of its character from the movement in the 'mother country." (114) More work beyond the 1901 to 1913 period and beyond Mann's and Ross' Australasian circle, adopting Kirk's network approach to transnationalism, might establish how the Anglophone world and beyond derived ideas from the socialism developing in the Antipodes.

Melanie Nolan

Australian National University

\section{Bridget Kenny, Retail Worker Politics, Race and Consumption in South Africa: Shelved in the Service Economy (Cham, Switzerland: Palgrave Macmillan 2018)}

WHY HAVE RETAIL worker labour politics endured, how have they changed, and to what effect? Bridget Kenny examines these important questions in the context of retail work in greater Johannesburg, pre-and post-apartheid, from the 1930s to 2013. Kenny's impressive historical ethnography is the result of 20 years of fieldwork research that included focus groups and interviews with retail workers, industry experts, retail managers, and retail union officials and shop stewards. Weaving together rich accounts of retail worker experiences, Kenny analyzes the labour relationship of retailing as a site of political terrain that constitutes the political subject of "workers" abasebenzi. The book details how retail worker politics have been shaped by three connected dynamics: retail as a space that constructs the nation and belonging; labour law and its part in creating the subject of the "employee" and constructing the boundaries within which workers resist; and the ways in which abasebenzi goes beyond being solely a worker identity and reflects a complex articulation of race, class, and gender relations.

The story begins by examining women's retail labour in Johannesburg from the 1930s to the 1970s. In Chapter 2, Kenny illuminates how white, working-class female shop assistants participated in complex retail relations that simultaneously challenged and re-constituted gender, race, and class relations. Working for pay at a time when white women were discouraged from doing so, the shop assistants serviced other white customers and contributed to the development of a city which symbolized modernity, belonging, and racial exclusivity through a developing consumer culture. Represented by the National Union of Distributive Workers (NUDW), white women retail workers in the 1930s were organized, held leadership roles in the union, and won improvements to wages and working conditions. At the same time, however, employers exercised control over female shop assistants by regulating their dress and appearance, and fathers and husbands exercised control over their work schedules and even decisions about whether or not to continue working after having children. By the 1960s, chain retailers were expanding and with larger stores came a re-organizing of the labour process. Corporate (male) hierarchies and management grew, and female shop assistants and cashiers had their work de-skilled, job tasks intensified, and autonomy threatened. In the late 1960s and 1970s, the growing retail industry faced white labour shortages, as white women moved into finance and public sector work, and consequently 
retailers began hiring Black workers into service jobs.

Chapter 3 examines the increasing entrance of Indian and Coloured women, and African men and women into retail work from the late 1960 s to 1980 s. The chapter details workers' experiences of discrimination in wages and hours of work, differential dress code requirements and job duties, as well as sexual harassment, that reinforced visible racial hierarchies and operated as ways for retail managers to maintain control while reproducing race and gender relations within workplaces. In this chapter readers learn how workers' access to means to challenge their discriminatory treatment mirrored the racist hierarchies that shaped retail workplaces. Under apartheid and labour law, the union that represented white retail workers (NUDW) had to create a parallel union to organize Indian and Coloured workers (the National Union of Commercial and Allied Workers or NUCAW). African workers would not have a union to join until 1975 and it was not until the early 1980s that the union was recognized. African workers, therefore, were especially subjected to workplace discrimination from managers, supervisors, and customers. Such conditions, Kenny explains, helped mobilize African workers to later join the Commercial Catering and Allied Workers Union of South Africa (CCAWUSA). The CCAWUSA provided a sense of belonging and helped form a collective political race-class subject (abasebenzi), while also creating a formal way to challenge marginalization and discriminatory working conditions.

One of the most interesting chapters, and a key contribution of the book, is Chapter 4. Chapter 4 provides a historical, socio-legal analysis of how South African labour operated to create the material conditions against and through which retail workers resist. Kenny examines how labour law was used by the state, trade unions, and employers to affirm and contest the boundaries of the "employee," a legal category constituted by gender and race relations. The chapter maps the multiple divisions within the category "employee" under South Africa's labour law regime pre- and postapartheid and shows how these divisions are shaped by presumptions about race, skill, and gender. For instance, the Wage Act (1925) which regulated basic working conditions and wages in the retail sector is analyzed for how it operated to protect the (white) male family wage by basing wages on occupational category, "skill," years of work experience, and gender. Kenny analyzes how forms of employment were constructed differently and took on different meanings depending on race, gender, and class. In the $1950 \mathrm{~s}$ for white women working in retail, parttime work was supported and protected as a respectable form of employment for married mothers (a perspective which also reinforced white women's status in retail work as secondary wage earners). Unlike the experiences of white women, rather than fighting for part-time positions as a way to protect women's roles as mothers, Black working-class women and CCAWUSA resisted employers' use of part-time work and fought for full-time employment. Finally, in this important chapter, readers learn that shortly after the Labour Relations Act (1982) unified the category of "employee" enabling Black workers to legally join trade unions, the state introduced labour brokering and retail workers soon after faced new challenges associated with temporary labour contracts.

In Chapter 5, Kenny recounts the restructuring of retail work from the 1970s to the 1980s and the subsequent effect on retail workers experiences of work. The growth of "hypermarkets" - large retail stores selling a combination of food and 
non-food goods - significantly changed the retail industry. Hypermarkets replaced the skilled retail shop assistance with a "self-service" model facilitated by meticulously controlling the store layout and aisle displays. With these changes cashiers were similarly de-skilled through employer use of computerized till technology which also brought increased employee surveillance. By the late 1990s, a corporate culture of surveillance turned Black workers into criminals and outsiders in their place of work. Employees were intensely monitored for theft, and management further changed working conditions by cutting employee benefits and lowering employment standards. Hypermarkets challenged the sense of belonging retail workers associated with their worksite and their collective political category as abasebenzi.

In reaction to these changes, in Chapter 6 Kenny focuses on the exciting ways retail workers resisted the challenges that came during the global transformation of retail work (between 1990 and the early 2000s). A unique contribution of this chapter (and indeed the book) is in examining informal and creative acts of worker resistance that go beyond the formal institutional power of law and trade unions. Kenny argues that forms of retail worker struggle during this moment re-constituted the abasbenzi, but in a manner that was internally divided and reflected differences based on employment categories and the unique identities and skills of workers within them. Permanent workers, for instance, could resist management decisions and changing work conditions using tactics that were riskier for casual workers to engage in (such as stopping work). Kenny shows how the various ways permanent, casual, and contract merchandisers (employed by labour brokers) were able to resist reinforced workplace hierarchies and distinctions between employment categories in ways marked by age, race, and gender relations.

Chapter 8 concludes by looking at WalMart's entry into South Africa through acquiring Massmart, and the subsequent construction of working-class Black consumers as the new market for Massmart's low cost goods. In this new era of Massmart/Wal-Mart's low-price consumer, retail workers experience even further deteriorating working conditions under the world's largest private sector employer, which Kenny details relies on low wage workers and precariously employed contract staff supplied by labour brokers.

Kenny's work is an impressively rich historical ethnography that covers nearly a century of retail worker politics. It brings attention to an underexplored and paradigmatic form of precarious work retail work. The book furthers research on retail worker politics by illuminating the complex ways retail workers in Johannesburg have contested labour relations, even as low wage, low "skill" workers in spaces not typically associated with worker power. In order to understand retail worker resistance, Kenny shows us how significant it is to understand the ways in which race, gender, and class constitute abasebenzi, a colletive political subject that mobilizes retail workers and fuels worker resistance.

Kaitlyn Matulewicz

University of British Columbia

\section{Valeria Vegh Weis, Marxism and Criminology: A History of Criminal Selectivity (Leiden: Brill 2017)}

MARXISM AND CRIMINOLOGY is the type of book no historian would ever write, but that all historians of policing and the state should read. It is full of big ideas and meta-analyses that our monographs often lack, and it has many crucial insights 